\title{
Surge-type glaciers in the Russian High Arctic identified from digital satellite imagery
}

\author{
Julian A. Dowdeswell, Meredith Williams \\ Centre for Glaciology, Institute of Geography and Earth Sciences, University of Wales, Aberystreyth Sr23 3DB, Wales
}

\begin{abstract}
Landsat digital imagery was used to search the island archipelagos of Franz Josef Land, Severnaya Zemlya and Novaya Zemlya, Russian High Arctic, for the presence of looped moraines characteristic of past glacier surges. The imagery provides almost complete summer-time coverage of the $60000 \mathrm{~km}^{2}$ of ice in these islands. Very few surge-type glaciers are identified: none in Franz Josef Land, three in Novaya Zemlya and two on Severnaya Zemlya. This contrasts greatly with Svalbard (ice-covered area $36600 \mathrm{~km}^{2}$, to the west, where $36 \%$ of glaciers and ice-cap drainage basins are inferred to surge. The strong climatic gradient across the Eurasian High Arctic, with decreasing temperature and moisture eastward, may provide a gross control on this pattern through colder glacier thermal structure, limiting basal drainage on the thinner ice masses in particular.
\end{abstract}

\section{INTRODUCTION}

The markedly non-random geographical distribution of surge-type glaciers is well known (e.g. Post, 1969; Paterson, 1994). Within the Russian and Norwegian Eurasian High Arctic islands (Fig. la), the Svalbard archipelago contains over 80 glaciers which have been observed during the active phase of the surge cycle (e.g. Liestol, 1969; Schytt, 1969; Dowdeswell and others, 1991; Hagen and others, 1993). In addition, glacier-surface characteristics, such as looped medial moraine systems (Meier and Post, 1969), have been used to infer that about $36 \%$ of ice masses within the $36600 \mathrm{~km}^{2}$ of ice in Svalbard may be of surge type (Hamilton and Dowdeswell, 1996). To the east of Svalbard, the Russian High Arctic archipelagos of Novaya Zemlya, Severnaya Zemlya and Franz Josef Land contain a total of about $60000 \mathrm{~km}^{2}$ of glaciers and ice caps (Dowdeswell and others, in press; Kotlyakov, in press) (Fig. 1). However, no glaciers of unequivocal surge type have, to our knowledge, been reported from these little-known islands (Kislov and Koryakin, 1986).

In this paper, we present evidence, in the form of digital Landsat satellite imagery, for the occurrence of a small number of surge-type glaciers in the Russian archipelagos of Novaya Zemlya and Severnaya Zemlya, and for an absence of surge-type glaciers in Franz Josef Land (Fig. 1).

\section{DATA ACQUISITION AND METHODS}

Digital satellite imagery from the Landsat Thematic Mapper (TM) was used as the main data source for this study (Table 1). The images covered over $95 \%$ of the glaciers and ice caps on Franz Josef Land, all of the ice on Severnava Zemlya and over $80 \%$ of the glaciers on the heavily glacierized northern island of Novaya Zemlya (Fig. 1). These TM scenes were supplemented by digital and photographic Landsat Multispectral Scanner (MSS) products (Table 1),
Table 1. Landsat Thematic Mapper (TM) and Multispectral Scanner (MSS) digital images of Russian High Arctic ice masses used in this study

\begin{tabular}{lclll}
\hline Path Row & Date & Sensor & Mission & \multicolumn{1}{c}{ Location } \\
\hline $157 / 004$ & 25.08 .88 & MSS & 5 & Severnaya Zemlya \\
$162 / 003$ & 28.08 .88 & MSS & 5 & Severnaya Zemlya \\
$164 / 003$ & 26.08 .88 & TM & 5 & Severnaya Zemlya \\
$165 / 003$ & 31.08 .87 & MSS & 5 & Severnaya Zemlya \\
$166 / 003$ & 24.08 .88 & MSS & 5 & Severnaya Zemlya \\
$171 / 002$ & 27.08 .88 & MSS & 5 & Severnaya Zemlya \\
$173 / 001$ & 25.08 .88 & MSS & 5 & Severnaya Zemlya \\
$174 / 001$ & 26.04 .88 & TM & 5 & Severnaya Zemlya \\
$178 / 006$ & 06.07 .86 & TM & 5 & Novaya Zemlya \\
$178 / 007$ & 06.07 .86 & TM & 5 & Novaya Zemlya \\
$196 / 001$ & 08.08 .87 & TM & 5 & FranzJosef Land \\
$197 / 001$ & 08.05 .83 & TM & 4 & FranzJosef Land \\
$197 / 001$ & 08.05 .83 & MSS & 4 & FranzJosef Land \\
$197 / 001$ & 01.08 .88 & TM & 5 & FranzJosef Land \\
$199 / 001$ & 25.07 .86 & TM & 5 & Eastern Franz Josef Land \\
$199 / 002$ & 25.07 .86 & TM & 5 & Western FranzJosef Land \\
\hline
\end{tabular}

which covered the remainder of the ice-covered area of these islands. Late-summer imagery was used, where available, as surface features diagnostic of glacier surging are best recognized on bare glacier ice.

A number of ice-surface features have been used as indicators of whether or not glaciers and larger ice masses have surged during the residence time of the ice within a given drainage basin (e.g. Meier and Post, 1969; Williams and others, 1991; Hambrey and Dowdeswell, 1994). These features include (Meier and Post, 1969; Sturm, 1987): (a) looped medial moraines, formed as fast-flowing, active-phase surge-type glaciers flow past less active or stagnant neighbours and deform the medial moraines between them, (b) potholes on the glacier surface during the quiescent phase, and (c) a heavily crevassed surface indicative of a glacier in the active phase of the surge cycle. These features can be recognized readily on Landsat TM imagery. 


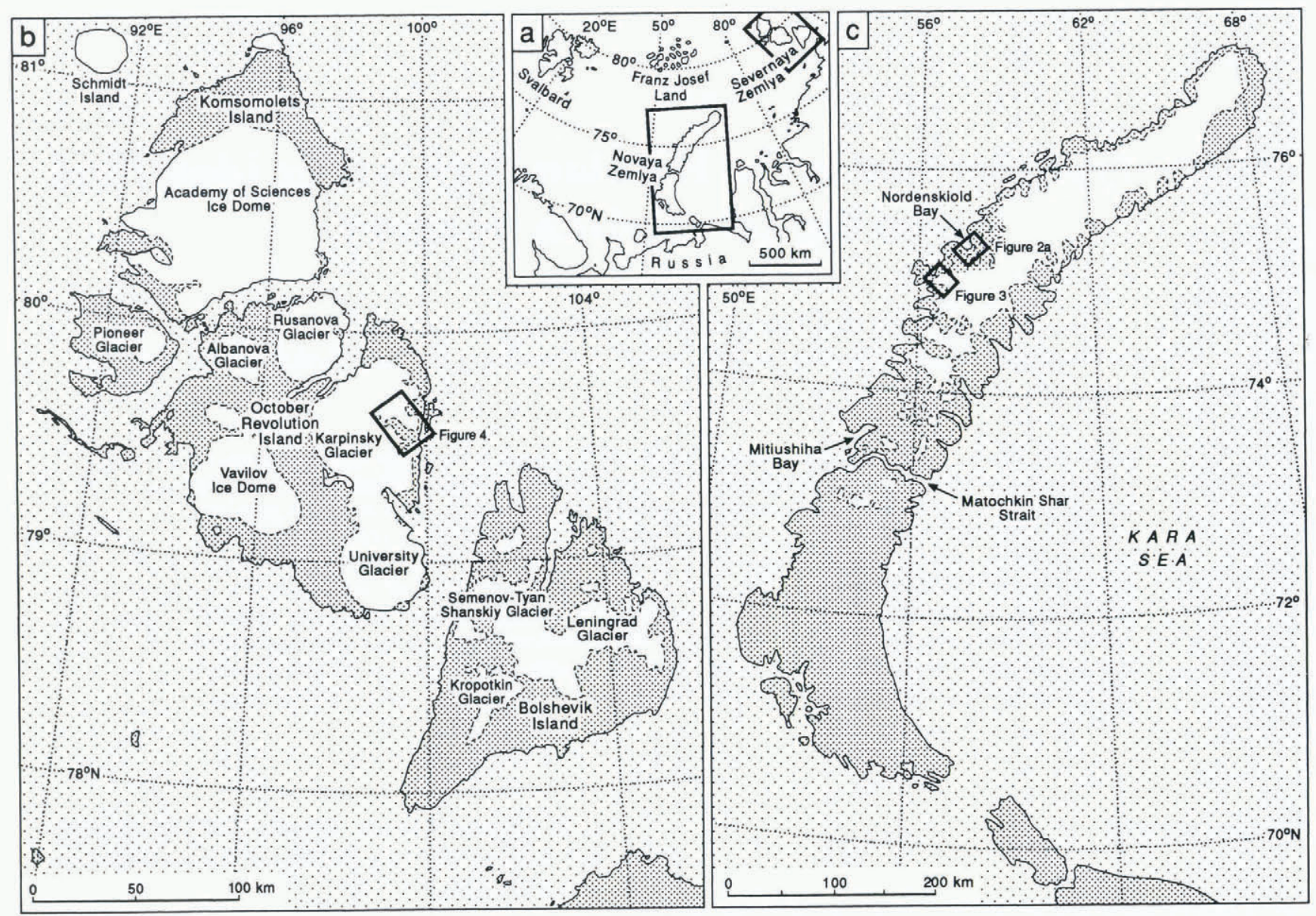

Fig. 1. (a) The archipelagos of the Eurasian High Arctic. Maps of the ice cover of (b) Severnaya Zemlya and (c) Novaya Zemlya. Boxes in $(b)$ and $(c)$ show locations of satellite images in subsequent figures.

Each digital or photographic image was examined systematically for the presence of such features in segments of between approximately 100 and $150 \mathrm{~km}^{2}$ using digital image-analysis software on a Sun-based system. The features are resolved easily at the $30 \mathrm{~m}$ or 79 by $56 \mathrm{~m}$ pixel size of the TM and MSS sensors, respectively. It should be pointed out that medial moraines are not formed on valley and cirque glaciers of the simplest geometry, with only a single trunk stream and no tributaries or isolated nunataks. However, distorted lateral moraines may be present. The absence of looped medial moraines on these very small glaciers, usually less than about $5 \mathrm{~km}^{2}$ in area, is therefore expected and is not diagnostic.

\section{RESULTS}

\section{Novaya Zemlya}

There are $24400 \mathrm{~km}^{2}$ of ice on the islands of Novaya Zemlya, comprising 685 glaciers according to the Russian glacier inventory (Kotlyakov, in press). Over $95 \%$ of this ice is concentrated in the largest, northern island (Fig. 1c). An extensive, elongate ice cap covers the central, northsouth trending spine of this island, and a number of outlet glaciers reach marine waters on both the eastern and western sides. Both the tide-water and land-terminating glaciers have been examined systematically but only two areas have been identified where looped medial moraines suggest the presence of surge-type glaciers.

In the Nordenskiöld Bay area of western Novaya Zemlya there is evidence of two systems with deformed medial mor- aines (Fig. 1c). These are shown in the Landsat TM images in Figure 2. One area, to the north in this sub-scene, ends in a tide-water glacier (Fig. 2a), and the second, more southerly glacier terminates on land (Fig. 2b). The northern ice front is about $4 \mathrm{~km}$ wide at its seaward margin and extends $35 \mathrm{~km}$ to the central ice divide on Novaya Zemlya. It is composed of five flow units, labelled A to E in Figure 2a.

Flow units $\mathrm{A}$ and $\mathrm{B}$, the most northerly, have a pattern of surface meltwater streams and potholes that is often found on surge-type glaciers in the quiescent phase (Meier and Post, 1969; Sturm, 1987). To the south, flow units B and C are separated by a strongly looped medial moraine. This is the most clear-cut indicator of surging within the series of flow units. The broad spread of surface debris, in the part of the loop transverse to ice flow, suggests an open-fold structure with fold axis plunging gently up-glacier. The material is probably composed of supraglacial debris of rockfall origin, derived from the nunatak up-glacier. This deformed medial moraine is similar to the folded moraines reported from the known surge-type glacier, Hessbreen, in Svalbard (Hambrey and Dowdeswell, 1997). Flow unit C has a prominent longitudinal foliation and large numbers of crevasses, mainly orientated normal to ice flow, over the lower $12 \mathrm{~km}$ or so (Fig. 2a). Crevassing above this point, if present, is likely to be obscured by the remaining summer snow cover. There are also indications of the calving of numerous small icebergs into the remaining sea-ice cover in the fjord. Both these features indicate active ice flow and suggest that the outlet-glacier system may be in the active phase of the surge cycle. However, although Hodgkins and Dowdeswell (1994) noted heavy crevassing on a number of Svalbard tide-water 

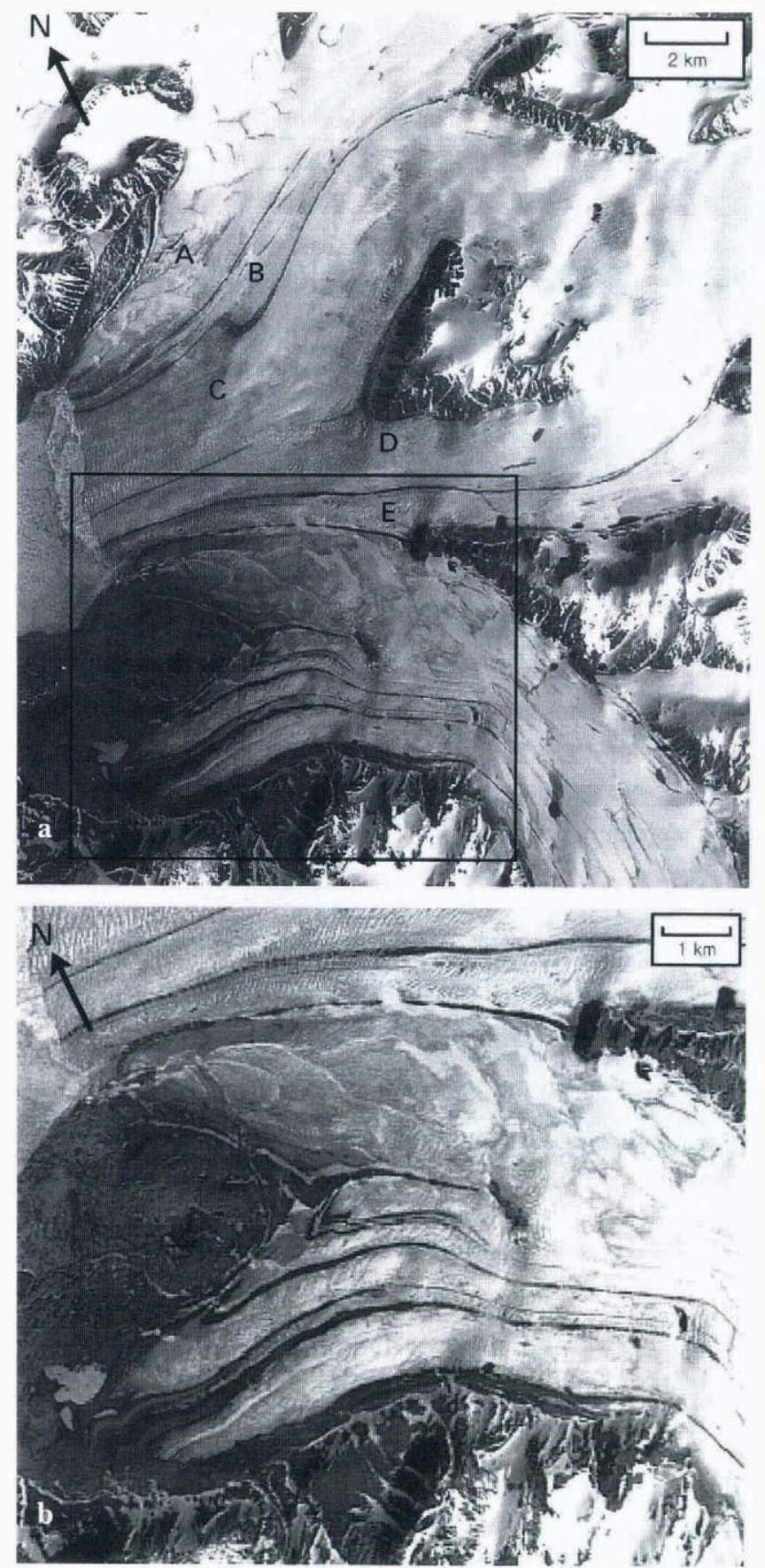

Fig. 2. (a) Digitally enhanced Landsat TM image of the outlet glaciers entering Nordenskiöld Bay, Novaya Zemlya. Flow units discussed in the text are labelled $A$ to $E$. The image is from path/row 178/007, acquired on 6 July 1986. The boxed area is enlarged in Figure $2 b$. (b) Detail from the Landsat image in Figure $2 a$, showing the three sets of deformed medial moraines on a glacier terminating on land immediately south of Nordenskiöld Bay, Novaya Zemlya. The images are located in Figure 1c.

glaciers in the active phase of the surge cycle, tide-water glaciers which do not surge are also known to be crevassed, especially adjacent to their margins. Flow units D and E also appear crevassed on satellite imagery (Fig. 2a) but this criterion alone, in the absence of looped moraines, is no more than suggestive of possible surge activity.

The glacier system ending on land to the immediate south of Nordenskiöld Bay (Fig. 2b) is smaller than the tide-water glacier system described above. It is only about $1 \mathrm{~km}$ wide and is associated with several other ice-flow units defined by medial moraines. It is identified as surge-type by the three sets of strongly deformed medial moraines imaged on the Landsat TM (Fig. 2b). The spacing of about $1.5 \mathrm{~km}$ between looped moraine set 1 and sets 2 and 3 suggests a record of at least two and perhaps three past surges (Meier and Post, 1969; Clarke, 1991). The glacier does not appear to be heavily crevassed. Its surface has the uneven topography characteristic of a low gradient and largely stagnant ice mass, suggestive of ablating crevasses and melt streams.

About $45 \mathrm{~km}$ further south, on the west side of Novaya Zemlya, a further group of distorted moraines is identified (Fig. 3). There is a marked kink in the moraine about $8 \mathrm{~km}$ from a glacier terminus ending partly in lake waters. Two sets of less-deformed moraines at about $4 \mathrm{~km}$ from the snout suggest possible past unstable flow. The many melt pools and streams on the ice surface are indicative of stagnant ice in the quiescent phase between surge activity.

\section{Severnaya Zemlya}

A thorough search of the $18320 \mathrm{~km}^{2}$ of ice on Severnaya Zemlya (Fig. lb), which includes 285 separately identified glaciers (Kotlyakov, in press), suggests that very few are of surge-type. Indeed, Kislov and Koryakin (1986) reported that there were no surge-type glaciers on Severnaya Zemlya.

The only looped moraines recognized on satellite imagery from Severnaya Zemlya are on two eastern outlets of Karpinsky Ice Dome on October Revolution Island (Fig. lb). The larger feature is located on a $9 \mathrm{~km}$ wide piedmont glacier descending from the ice-cap crest about $25 \mathrm{~km}$ to the west (Fig. 4). It has the appearance of being composed of both medial morainic debris and foliated ice. It is inactive at present and suggests past unstable flow derived from the area to the north of the nunatak marked $\mathrm{A}$ in Figure 4.

The smaller moraine features are located on an outlet glacier immediately to the south on Karpinsky Ice Dome (Fig. 4). This outlet glacier is only about $15 \mathrm{~km}$ in length and between about 1 and $2 \mathrm{~km}$ wide. The moraines on the right and left sides of this outlet are looped. The glacier appears uncrevassed at present and so is not in the active phase of the surge cycle.

This evidence, indicating possible past surges on Severnaya Zemlya appears more equivocal than the strongly looped moraine systems identified from Novaya Zemlya (Fig. 2).

\section{Franz Josef Land}

No looped moraine systems were observed on digital or analogue Landsat imagery of the $13700 \mathrm{~km}^{2}$ of ice on the islands of Franz Josef Land (Fig. la). It is inferred from this observation that at least the bulk of the 995 individual glaciers identified in inventories of the archipelago (Grosval'd and others, 1973; Kotlyakov, in press) are unlikely to have undergone recent surges.

Kloster (1991) reported a relatively rapid retreat and associated iceberg production from Znemenity Glacier on Vilchek Land, in the east of the archipelago. He suggested that this activity, in the largest ice-cap drainage basin on Franz Josef Land (Dowdeswell and others, 1995a), may possibly have been linked to a past surge. However, terminus retreat alone is not a diagnostic indicator of past surge activity. In addition, further satellite imagery examined by Kloster and Spring (1993) showed that the ice front of Znemenity Glacier re-advanced by several hundred metres between 1989 and 1991, suggesting that the previously observed 


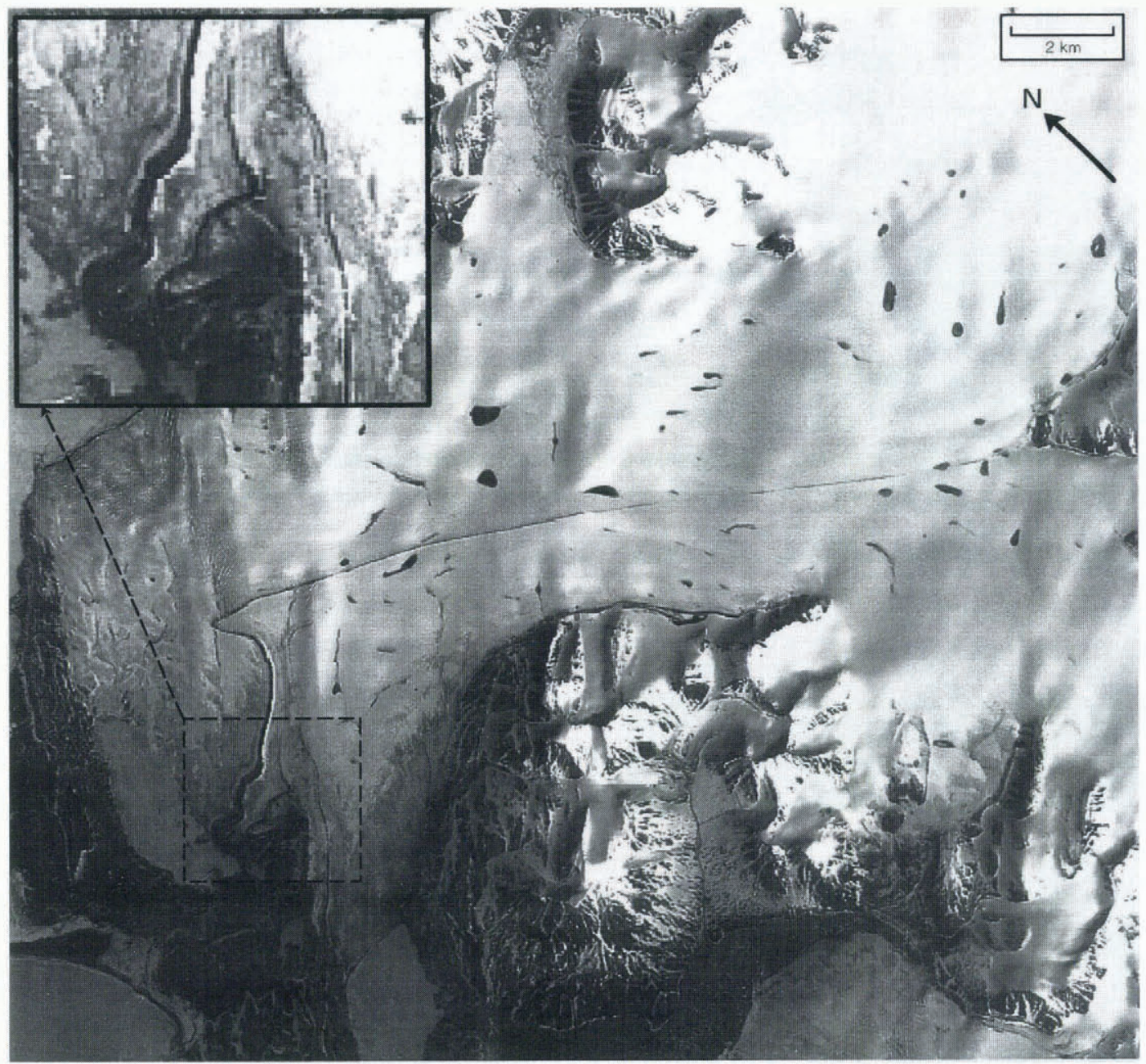

Fig. 3. Looped medial moraines on a glacier draining the southwestern part of the ice cap on. Novaya Zemlya. The inset shows detail of the looped moraines. The Landsat TM sub-scene is from path/row 178/007 acquired on 6 July 1986.

retreat was part of a continuing adjustment associated with periodic iceberg calving.

\section{DISGUSSION}

The markedly non-random geographical distribution of surge-type glaciers has been recognized for some time (Meier and Post, 1969; Post, 1969). The lack of such glaciers in the Russian High Arctic contrasts with the large number of ice masses, ranging from small valley glaciers to large ice-cap drainage basins, which have been observed to surge or are inferred to have surged in Svalbard (Schytt, 1969; Dowdeswell, 1986; Dowdeswell and others, 1991; Hagen and others, 1993). That archipelago is only about $200 \mathrm{~km}$ west of Russian Franz Josef Land (Fig. la).

Climatic conditions vary considerably across the Eurasian High Arctic and will, in turn, affect the patterns of glacier mass balance and thermal structure. There is a strong climatic gradient from warmer, wetter conditions in Svalbard to progressively colder and more arid conditions eastward across the Eurasian High Arctic. This gradient is associated with the decreasing influence of the northwardtracking warm depressions and ocean currents which affect western Svalbard in particular. Thus, the mean annual surface temperature in Svalbard is about $-6^{\circ} \mathrm{C}$, as compared with $-9^{\circ} \mathrm{C}$ in Novaya Zemlya, $-12^{\circ} \mathrm{C}$ in Franz Josef Land and $-15^{\circ} \mathrm{C}$ in Severnaya Zemlya (Dowdeswell, 1995). These relatively cold conditions, combined with lower ice-surface accumulation rates, less meltwater refreezing and, in Franz Josef Land, ice that is usually less than $300-400 \mathrm{~m}$ in thickness (Dowdeswell and others, 1996), implies that a significant proportion of Russian High Arctic glaciers may be frozen to their beds and therefore unable to undergo the rapid basal sliding associated with glacier surging.

There is also evidence, in the form of ice-core records and measurements of widespread glacier retreat, that the Russian High Arctic, like Svalbard to the west, has undergone warming over the last 100 years or so associated with the end of the cold "Little Ice Age" (e.g. Koryakin, 1986; Govorukha, 1988; Tarussov, 1992). As a result of this warming, and the associated shift towards consistently negative glacier mass balance in Svalbard (Hagen and Liestøl, 1990; Lefauconnier and Hagen, 1990), some glaciers which formerly surged are now apparently unable to build up the reservoir-area mass and geometry for a new surge (Dowdeswell and others, 1995b). In addition, smaller glaciers may have thinned to the point at which they have become frozen to their beds (Dowdeswell and others, 1995b). However, the lack of evidence for past surges in the Russian High Arctic islands indicates that conditions may have been unfavourable for surging even before the end of the Little Ice Age.

Hamilton and Dowdeswell (1996) also found a statistically significant relationship between the occurrence of surge-type glaciers and sedimentary bedrock in Svalbard. 


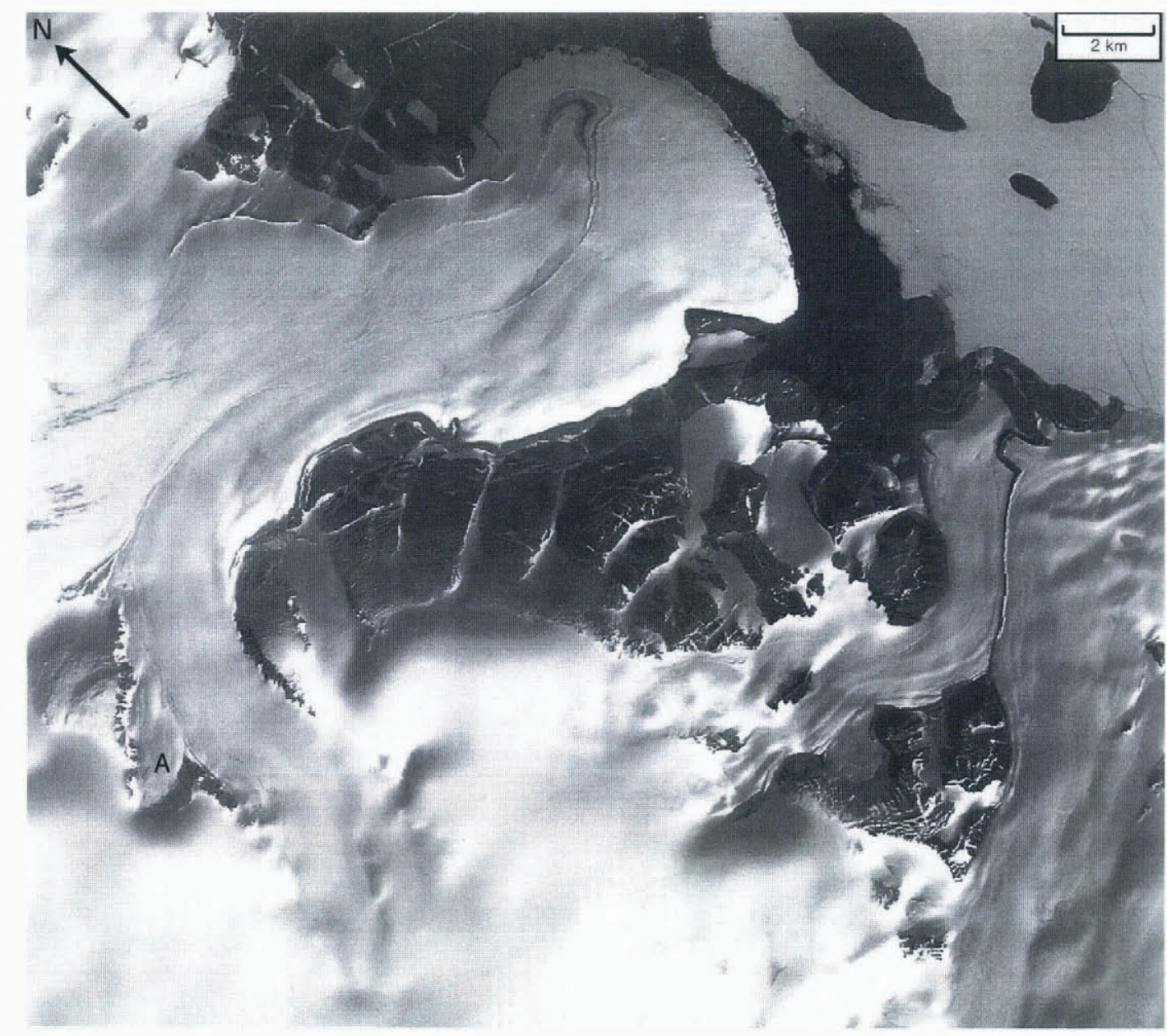

Fig. 4. Deformed medial moraines on two outlet glaciers of the Karpinsky Ice Dome on October Revolution Island, Severnaya Zemlya. The Landsat TM sub-scene is from path/row 164/003 acquired on 26 August 1988.

A similar link between bed lithology and surging was also noted qualitatively by Post (1969) for western North American glaciers and by Weidick and others (1992) in West Greenland. This may be related, in turn, to the presence of deformable basal sediments and a surge mechanism involving changing hydrological conditions within deformable beds (Clarke and others, 1984). However, on Franz Josef Land, for example, both very resistant basaltic sheets and friable sedimentary rocks are found (Glazovskij, 1995), yet no glaciers are observed to surge on either bedrock type. Finally, neither possible climatic nor gross geological influences on the distribution of surge-type glaciers explains the detailed mechanisms controlling the triggering of surges on individual glaciers in the Eurasian High Arctic or elsewhere.

\section{CONCLUSIONS}

The principal finding of this study is that there are apparently very few glaciers and ice-cap drainage basins of surge type within the major icc-covered archipelagos of the Russian High Arctic. We have identified only five probable surge-type glaciers using the well-established criterion of looped moraines identified from Landsat satellite imagery. This provides a marked contrast with the large number of surge-type glaciers and ice caps in Svalbard to the west (Fig. 1). This gross geographical change in surge occurrence may be related in part to the strong climatic gradient towards colder and drier conditions eastward across the Eur- asian Arctic, with a consequent increase in the number of glaciers that are frozen to their beds, and perhaps also to the presence of resistant igneous and metamorphic rocks in some areas of the Russian Arctic. Negative mass balances since the end of the "Little Ice Age" about 100 years ago, may also limit the geometric build-up of glaciers towards further surges. It is possible that some small glaciers of simple geometry are of surge-type but have remained undetected in our survey.

It is also possible that we have missed some surge-type glaciers owing to the $30-80 \mathrm{~m}$ resolution of the Landsat series sensors, the particular surface conditions at the time of image acquisition and the small gaps in our spatial coverage. Finally, some surges may have been reported in the literature, and the Russian literature in particular, of which we are unaware despite careful searching. However, it is clear from our study that relatively few glaciers and ice-cap drainage basins in the Russian High Arctic are of surge type.

\section{ACKNOWLEDGEMENTS}

This project was funded through U.K. Natural Environment Research Council grant GR3/9958 and INTAS grant 1010-CT93-0006 to J. A. D. We thank E. K. Dowdeswell, A. F. Glazovsky, M.J. Hambrey and G. S. Hamilton for comments on this paper. 


\section{REFERENCES}

Clarke, G. K. C., S. G. Collins and D. E. Thompson. 1984. Flow, thermal structure, and subglacial conditions of a surge-type glacier. Can. J. Earth Sci., 21 (2), 232-240.

Clarke, T. S. 1991. Glacier dynamics in the Susitna River basin, Alaska, U.S.A. J. Glaciol., 37(125), 97-106.

Dowdeswell, J. A. 1986. Drainage-basin characteristics of Nordaustlandet ice caps, Svalbard. F. Glaciol., 32(110), 31-38.

Dowdeswell, J. A. 1995. Glaciers in the High Arctic and recent environmental change. Philos. Trans. R. Soc. London, Ser. A, 352 (1699), 321-334.

Dowdeswell, J. A., G. S. Hamilton and J. O. Hagen. 1991. The duration of the active phase on surge-type glaciers: contrasts between Svalbard and other regions. J. Glaciol., 37 (127), 388-400.

Dowdeswell, J. A., A. F. Glazovsky and Y.Y. Macheret. 1995a. Ice divides and drainage basins on the ice caps of Franz Josef Land, Russian High Arctic, defined from Landsat, KFA-1000, and ERS-1 SAR satellite imagery. Arct. Alp. Res., 27 (3), 264-270.

Dowdeswell, J. A., R. Hodgkins, A. -M. Nuttall, J. O. Hagen and G. S. Hamilton. 1995b. Mass balance change as a control on the frequency and occurrence of glacier surges in Svalbard, Norwegian High Arctic. Geophys. Res. Lett., 22 (21), 2909-2912.

Dowdeswell, J. A., M. R. Gorman, A. F. Glazovsky and Y.Y. Macheret. 1996. Airborne radio-echo sounding of the ice caps on FranzJosef Land in 1994. Mater. Glyatsiol. Issled. 80, 248-254.

Dowdeswell, J. A., E. K. Dowdeswell, M. Williams and A. F. Glazovsky. In press. The glaciology of the Russian High Arctic from Landsat imagery. U.S. Geol. Surv. Prof. Pap.

Glazovskij, A. F. 1995. Geology. In Barr, S. ed. Franz Josef Land. Oslo, Norsk Polarinstitutt; Salzburg, University of Salzburg, 22-26. (Polarhåndbok 8.)

Govorukha, L. S. 1988. The present state of ice cap islands in the Soviet Arctic. Polar Geogr. Geol., 12 (4), 312-316.

Grosval'd, M. G. and 6 others. 1973. Oledeneniye Zemli Frantsa-Iosifa / Glaciers of Franz Josef Land ]. Moscow, Izdatel'stvo "Nauka".

Hagen, J. O. and O. Liestøl. 1990. Long-term glacier mass-balance investigations in Svalbard, 1950-88. Ann. Glaciol., 14, 102-106.

Hagen, J. O., O. Liestøl, E. Roland and T. Jorgensen. 1993. Glacier atlas of Svalbard and Jan Mayen. Nor. Polarinst. Medd. 129.

Hambrey, M.J. and J. A. Dowdeswell. 1994. Flow regime of the Lambert Glacier-Amery Ice Shelf system, Antarctica: structural evidence from Landsat imagery. Ann. Glaciol., 20, 401-406.

Hambrey, M. J. and J. A. Dowdeswell. 1997. Structural evolution of a surgetype polythermal glacier: Hessbreen, Svalbard. Ann. Glaciol., 24, 375-381.
Hamilton, G. S. and J. A. Dowdeswell. 1996. Controls on glacier surging in Svalbard. f. Glaciol., 42(140), 157-168.

Hodgkins, R. and J. A. Dowdeswell. 1994. Tectonic processes in Svalbard tide-water glacier surges: evidence from structural glaciology. $\vec{J}$. Glaciol., $40(136), 553-560$.

Kislov, A.V. and V. S. Koryakin. 1986. Prostranstvennyye i vremennyye zakkonomernosti izmeneniy lednikov Yevraziyskoy Arktiki [Spatial and temporal regularities of glacier fluctuations in Eurasian Arctic]. Mater. Glyatsiol. Issled. 57, 120-125 (Russian); 236 - 241 (English).

Kloster, K. 1991. Satellite analysis of glaciers on Zemlya Frantsa-Iosifa. Bergen, Nansen Environmental and Remote Sensing Center. (Technical report 42.

Kloster, K. and W. Spring. 1993. Iceberg and glacier mapping using satellite optical imagery during the Barents Sea Ice Data Acquisition Program (IDAP). In POAC'93. The 12th International Conference on Port and Ocean Engineering under Arctic Conditions, 17-20 August 1993, Hamburg. Proceedings. Vol. 1. Hamburg, Department of Ice and Environmental Technology. Hamburg Ship Model Basin, 413-424.

Koryakin, V. S. 1986. Decrease in glacier cover on the islands of the Eurasian Arctic during the 20th century. Polar Geogr. Geol., 10 (2), 157-165.

Kotlyakov, V. M. In press. Glaciers of the former Soviet Union. U.S. Geol. Surv. Prof. Pap.

Lefauconnier, B. and J. O. Hagen. 1990. Glaciers and climate in Svalbard: statistical analysis and reconstruction of the Brøggerbreen mass balance for the last 77 years. Ann. Glaciol., 14, 148-152.

Liestøl, O. 1969. Glacier surges in west Spitsbergen. Can. J. Earth Sci., 6(4), Part 2, 895-897.

Meier, M. F. and A. Post. 1969. What are glacier surges? Can. J. Earth Sci., 6 (4), Part 2, 807-817.

Paterson, W. S. B. 1994. The physics of glaciers. Third edition. Oxford, etc., Elsevier.

Post, A. 1969. Distribution of surging glaciers in North America. F. Glaciol., 8 (53), $229-240$.

Schytt, V. 1969. Some comments on glacier surges in eastern Svalbard. Can. 7. Earth Sci., 6(4), Part 2, 867-873.

Sturm, M. 1987. Observations on the distribution and characteristics of potholes on surging glaciers. f. Geophys. Res., 92 (B9), 9015-9022.

Tarussov, A. 1992. The Arctic from Svalbard to Severnaya Zemlya: climatic reconstructions from ice cores. In Bradley, R. S. and P. D. Jones, eds. Climate since A.D. 1500. London and New York, Routledge, 505-516.

Weidick, A., C. E. Bøggild and N. T. Knudsen. 1992. Glacier inventory and atlas of West Greenland. Gronlands Geologiske Undersogelse, Ser. Rapport 158

Williams, R.S., Jr, D.K. Hall and C.S. Benson. 1991. Analysis of glacier facies using satellite techniques. F. Glaciol., 37 (125), 120-128. 